among the practical men as against the more scientific, though for the life of us we cannot see the advantage of a man who is only practical over one who, besides that, uses the experience of others as recorded in books and papers."

There is not one word in "Mad Doctors" to justify this. The author's whole argument is backing empiricism, or the deductive method against the inductive method. He defines empiricism thus:- "Practice based upon experience, not theory." He says that doctors do good "because they trust to their own experience or the communicated experience of others." Here the author uses exactly the same words as the critic, says precisely what the critic believes the writer ought to have said.

The author considers himself highly scientific, and, as such, he objects to the "ex uno disce omnes" of the weekly articles of the "Lancet" and "British Medical." As such he requires that long series of test cases should be given when any new treatment is published; as such he compares the "a priori reasoning in the chemical laboratory" with the exact methods of true . "ence, and learns a sorrowful lesson.

They are the truly scientific who are the most sceptical.

The critic has an unkind little laugh at the author, when he states that in illness the medical agnostic would become a medical believer, accept the medical faith, and probably swallow the pharmacopeia, if necessary, for the salvation of his body.

The author can only say that this argument is parallel to that of the clergyman who said that agnostics always believed in God in the hour of death.

Neither argument is true, and, were either true, it would only prove that the brain is a very imperfect organ, and that the throne of reason rests upon a narrow base, the base being bodily health.

February, 1891.

THE AUTHOR OF "MAD DOCTORS."

\title{
RATING OF ASYLUMS (LUNACY ACT, 1890).
}

To THE EDITORs or The Journal of Mental science.

GENTLEMEN,-The following copy of a letter recently (17th March) received from the Local Government Board may be of interest in connection with the short paragraph under the above heading in the last number of the Journal.

"With reference to your inquiry as to whether the rates paid in respect of the County Lunatic Asylums should be charged to the maintenance account, I am directed to state that the Board consider that the amount of the rate shonld not be eharged to the maintenanoe acconnt, but to the building and repairs and farming and gardening accounts, according to the ciroumstances, as shown in the forms of the financial tables prescribed by the Board's General Order of the 23rd June last."

This may be taken as an authority for debiting the accounts named with the new charge instead of making the maintenance the sole sufferer, and the d cision, whether right or wrong, is satisfactory as enabling asylums to act uniformly in this matter without any fear of our new bogie man-the Government Auditor-before our eyes.

$$
\text { I am, Gentlemen, }
$$

$$
\text { Your obedient Servant, }
$$

Burntwood Asylum, near Lichfield, 